\title{
Commercial Laundry Water Characterisation
}

\author{
J. K. Braga*, M. B. A. Varesche \\ Department of Hydraulics and Sanitation, Engineering School of São Carlos, São Paulo University, São Carlos, Brazil \\ Email: jukawanishi@gmail.com, varesche@sc.usp.br
}

Received November 22, 2013; revised December 24, 2013; accepted January 2, 2014

Copyright (C) 2014 J. K. Braga, M. B. A. Varesche. This is an open access article distributed under the Creative Commons Attribution License, which permits unrestricted use, distribution, and reproduction in any medium, provided the original work is properly cited. In accordance of the Creative Commons Attribution License all Copyrights (C) 2014 are reserved for SCIRP and the owner of the intellectual property J. K. Braga, M. B. A. Varesche. All Copyright (C) 2014 are guarded by law and by SCIRP as a guardian.

\begin{abstract}
Surfactants are the major active ingredients of laundry detergents. Therefore, special attention should be focused on the treatment and disposal of laundry wastewater. The aim of this study was to characterise the wastewater from a commercial laundry over 30 days. Physicochemical analyses were performed, monitoring the content of nitrogen, phosphate, heavy metals, linear alkylbenzene sulphonate (LAS), volatile organic acids and alcohols. The pH was approximately 5.6 and the COD approximately $4800 \mathrm{mg} \cdot \mathrm{L}^{-1}$. The average concentrations of sulphate, sulphide, $\mathrm{N}$-ammoniacal organic nitrogen compounds and heavy metals were below the maximum limit, in accordance with local and national environmental legislation, and the average total suspended solids was $0.08 \mathrm{~g} \cdot \mathrm{L}^{-1}$. Among the metals analysed, iron was observed with the highest concentrations $\left(0.037 \mathrm{mg} \cdot \mathrm{L}^{-1}\right.$ and $\left.0.72 \mathrm{mg} \cdot \mathrm{L}^{-1}\right)$. Phosphate was detected in $93 \%$ of samples (94.65 mg $\cdot \mathrm{L}^{-1}$ average). LAS was detected in all samples $\left(12.24 \mathrm{mg} \cdot \mathrm{L}^{-1}\right.$ to $\left.1023.7 \mathrm{mg} \cdot \mathrm{L}^{-1}\right)$. Thirty-three different xenobiotic organic compounds were identified in the laundry wastewater with the qualitative screening. The major groups of the compounds were fragrances, preservatives, solvents and some surfactants. Although the characterisation indicated low values for many parameters, this does not eliminate the need for specific treatment before its disposal at the sewage system.
\end{abstract}

\section{KEYWORDS}

\section{Greywater; Linear Alkylbenzene Sulphonate; Legislation; Xenobiotic Organic Compound; Heavy Metal}

\section{Introduction}

Through biological treatment, the regulated pollutants can be reduced to an acceptable concentration or converted into harmless substances. However, even today, some wastewater is disposed of in rivers, lakes and oceans without proper treatment. Among pollutants, detergents have been highlighted as an important source of industrial, commercial and domestic pollution, especially in large urban centres.

Pollution discharges containing surfactants cause severe changes to biota because the activities of many aquatic organisms depend fundamentally on water surface tension. Anionic surfactants can bind to peptides, enzymes, and DNA. Binding to proteins and peptides may change the folding of the polypeptide chain and the surface charge of a molecule. This may modify the biological function [1].

${ }^{*}$ Corresponding author.
The presence of synthetic compounds from greywater in natural waters leads to aesthetic losses caused by foam, which can cause toxic effects on ecosystems and changes in biodiversity. Greywater is wastewater that contains surfactant as its primary component, from baths, showers, hand wash basins, washing machines, dishwashers and kitchen sinks, but excludes input from toilets [2].

The composition of greywater varies greatly according to its origin (i.e., bathroom, laundry or kitchen greywater) and is influenced by different plumbing fixtures (shower, dishwasher, kitchen sink etc.). The source not only generates different amounts of greywater but also different pollutant sources and loads [3].

The treatment of laundry water is currently a subject of great challenge because intense population growth is not accompanied by infrastructure improvements, especially in the field of sanitation. Greywater characteristics play an important role when they are evaluated for the possibility of reuse, including the need for treatment. Public 
health aspects, especially the presence of xenobiotic organic compounds and heavy metals, must be taken into account [4].

Laundry water contains varying levels of suspended solids, salts, nutrients, organic matter and pathogens [5] that arise from clothes and laundry detergents and fabric softener residues.

Detergents are the most abundant organic chemicals in municipal wastewater [6]. As a consequence, this sets up a precarious situation with regard to population health and environmental conservation. Thus, it is extremely important to characterise this wastewater, as well as to develop economically viable and efficient technology that allows the widespread application of treatment systems that are favourable to the improvement of sanitary conditions. Due to their widespread use, surfactants are often found in municipal wastewater and in receiving bodies of water.

Evaluation of the appropriate treatment method should therefore be based on knowledge of a wastewater's specific characteristics. The information available regarding greywater characteristics focuses mainly on the content of organic matter (COD) and nutrients (N, P, K), while knowledge of the content of xenobiotic organic compounds (XOCs) is limited [7].

The dominating source of XOCs in greywater is expected to be household chemicals, e.g., laundry detergents, fabric softeners, dish-washing liquids, cleaning detergents, shampoos, soaps and toothpastes, even though some small contribution from sources like softeners from leaching pipes cannot be excluded.

Bathroom greywater screening from a Danish apartment block recorded the presence of almost 200 such XOCs, including surfactants, antioxidants, preservatives, fragrances, plasticisers, UV-filters and solvents, a number of which were also suspected endocrine disruptors [8].

Unfortunately, the current knowledge gaps regarding the presence and fate of micropollutants in greywater make it difficult to adequately determine the level of risk associated with non-standard water quality parameters, and the potential added value of greywater treatment as a micro-pollutant barrier has effectively remained untested to date [9].

The fate of compounds in the treatment system is dictated by their chemical structure, which greatly influences their rate of degradation and removal [10]. A simple compound that has a short alkyl chain is liable to be easily degraded in a biological treatment system. Hence it is necessary to know all the compounds present in the wastewater to be treated.

The aim of this study was to characterise the chemical composition and physical properties of commercial laundry water and to collect information on the presence of the XOCs. Because there is insufficient knowledge of greywater characteristics, there is an urgent need for more of this information to evaluate issues such as the chemical risk potential for greywater reuse and its effects on receiving water bodies [7-11].

\section{Experimental}

\subsection{Laundry Water Collection}

For this study, greywater from a commercial laundry (São Carlos, São Paulo, Brazil) was characterised by physical-chemical analyses. Water was collected three times a week, with a total of 30 samples. The washing machine, type of clothing and collection period were all standardised for this study. Samples (one litre) were always collected after the first wash of light-coloured clothes without bleach, prior to the addition of softener. The samples were collected in borosilicate glass bottles and transported in the dark to the research facilities.

\subsection{Physical-Chemical Analyses}

Analyses were performed immediately after sample collection at the Laboratory of Biological Processes in the School of Engineering of São Carlos/USP Brazil. The physical-chemical parameters are listed in Table 1. The SPSS 17.0 statistical package was used for Kendall and Spearman correlations analysis between COD and LAS present in water samples from the commercial laundry. The samples were stored in the refrigerator until the analyses were finalised.

Physical-chemical analyses of $\mathrm{pH}$, chemical oxygen demand (COD), sulphate, sulphide, heavy metals, total Kjeldahl nitrogen series, ammonia, and suspended solids were determined according to the Standard Methods for the Examination of Water and Wastewater [12], and alkalinity was determined according to [13] and [14].

The analysis of nitrate, nitrite, phosphate, fluoride, and bromide was performed in an Ion Chromatography Dionex model ICS 5000 (Thermo Fisher, Sunnyvale, CA, USA). The conditions employed in chromatography were as follows: an eluent composed of $4.5 \mathrm{mMNa}_{2} \mathrm{CO}_{3} / 0.8$ $\mathrm{mM} \mathrm{NaHCO}$ with a flow rate of $1.0 \mathrm{~mL} \cdot \mathrm{min}^{-1}$, an ION PAC AS23 column, temperature of $30^{\circ} \mathrm{C}$, conductivity detector, and an anion self-regenerating suppressor.

\subsection{Chromatographic Analyses}

Volatile organic acids were determined by high-performance liquid chromatography (HPLC) equipped with a pump (LC-10ADVP), auto sampler (SIL-20A HT), column oven (CTO-20A) at $43^{\circ} \mathrm{C}$, UV-diode array detector (SDP-M10 AVP), refraction index detector (RID-10A), system controller (SCL-10AVP) and an Aminex HPX$87 \mathrm{H}$ column $\left(300 \mathrm{~mm}, 7.8 \mathrm{~mm}\right.$, BioRad $\left.{ }^{\circledR}\right)$, the mobile phase consisted of $\mathrm{H}_{2} \mathrm{SO}_{4}(0.01 \mathrm{~N})$ at $0.5 \mathrm{ml} \cdot \mathrm{min}^{-1}$ [15]. Alcohols were determined by Gas Chromatography (GC) on a 2010 Shimadzu $^{\circledR}$ equipped with a HP-INNOWAX column and flame ionisation detector using hydrogen as 
Table 1. Physico-chemical parameters of commercial laundry water.

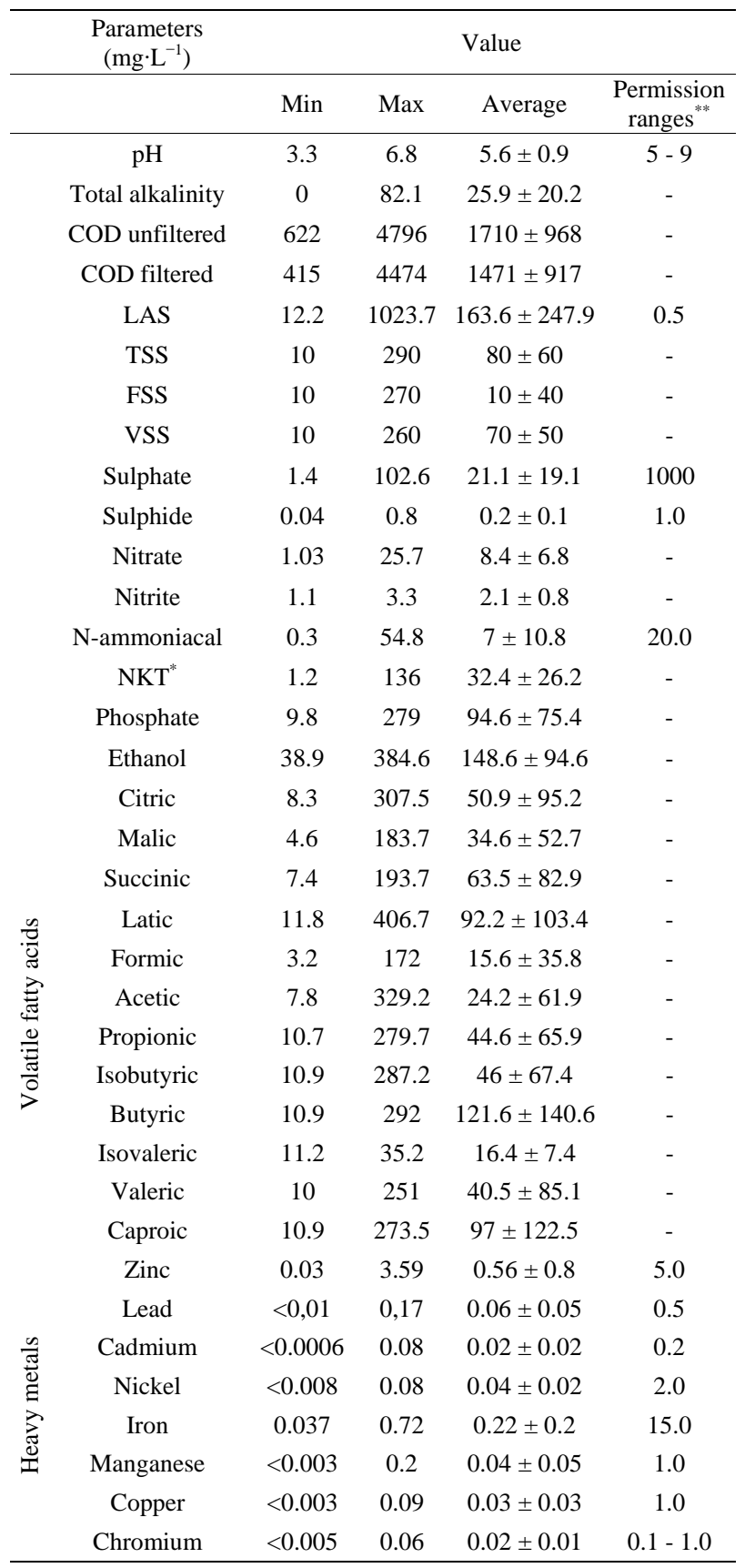

${ }^{* *}[22,30,31]$ and ${ }^{*} \mathrm{NKT}=$ nitrogen kjeldahl total.

carrier gas with synthetic air and nitrogen as auxiliary gases.

LAS determination was carried out according to the methodology developed and validated by [16]. This method employs HPLC $\left(\right.$ Shimadzu $\left.^{\circledR}\right)$ with a fluorescence detector, a C8 reverse phase column (Supelco) with agradient elution using methanol and sodium perchlorate $(0.075 \mathrm{M})$ at a $0.5 \mathrm{~mL} \cdot \mathrm{min}^{-1}$ flow rate and a temperature of $35^{\circ} \mathrm{C}$.
The other method selected for characterisation consisted of a GC-MS screening to identify organic substances, with the purpose of identifying the XOCs present. Analyses by the headspace of the samples were conducted by heating to $70^{\circ} \mathrm{C}$ for five minutes, and the vapours generated were analysed by GC-MS. For the analysis by direct injection, the sample was extracted in dichloromethane, concentrated and analysed by GC-MS. Equipment: mass spectrometer quadrupole linear Shimadzu QP-5000.

\section{Results and Discussion}

\subsection{LAS in Laundry Water}

LAS was observed in all samples, from $12.24 \mathrm{mg} \cdot \mathrm{L}^{-1}$ to $1023.7 \mathrm{mg} \cdot \mathrm{L}^{-1}$ (Table 1 and Figure 1). The lowest value detected in this study was similar to that found by others authors [17], which registered 4.7 to $15.6 \mathrm{mg} \cdot \mathrm{L}^{-1}$ for anionic surfactants and $839 \pm 47 \mathrm{mg} \cdot \mathrm{L}^{-1}$ for COD in greywater used for lettuce irrigation.

The sales for the US laundry detergent market in 1999 was $\$ 4.7$ billion, and the consumption of surfactants reached \$7.2 million tons in 2002 [18].

In this study, the average LAS concentration (163.65 $\mathrm{mg} \cdot \mathrm{L}^{-1}$ ) was much higher than that shown by other authors. In wastewater and soil were found anionic surfacetants around $29 \mathrm{mg} \cdot \mathrm{L}^{-1}$ to $60 \mathrm{mg} \cdot \mathrm{L}^{-1}$ and $23 \pm 4.5 \mathrm{mg} \cdot \mathrm{kg}^{-1}$, respectively [19]. These surfactants may be toxic to the organisms present in soil and some plants in these concentrations [6].

In characterising greywater for fertirrigation, [20] recorded concentrations between $0.7 \mathrm{mg} \cdot \mathrm{L}^{-1}$ and $70 \mathrm{mg} \cdot \mathrm{L}^{-1}$, with an average of $16.7 \mathrm{mg} \cdot \mathrm{L}^{-1}$ for anionic surfactants (using the MBAS method). This was generally higher than the anionic surfactant concentrations found in raw domestic wastewater, which reached $10 \mathrm{mg} \cdot \mathrm{L}^{-1}$, with an average of $5.4 \mathrm{mg} \cdot \mathrm{L}^{-1}$.

Greywater of 32 homes was characterised [21]. In this case $41.1 \pm 12.1 \mathrm{mg} \cdot \mathrm{L}^{-1}, 1.7 \pm 0.8 \mathrm{mg} \cdot \mathrm{L}^{-1}$ and $11.3 \pm 3.9$ $\mathrm{mg} \cdot \mathrm{L}^{-1}$ of anionic (sodium dodecylbenzene sulphonate),

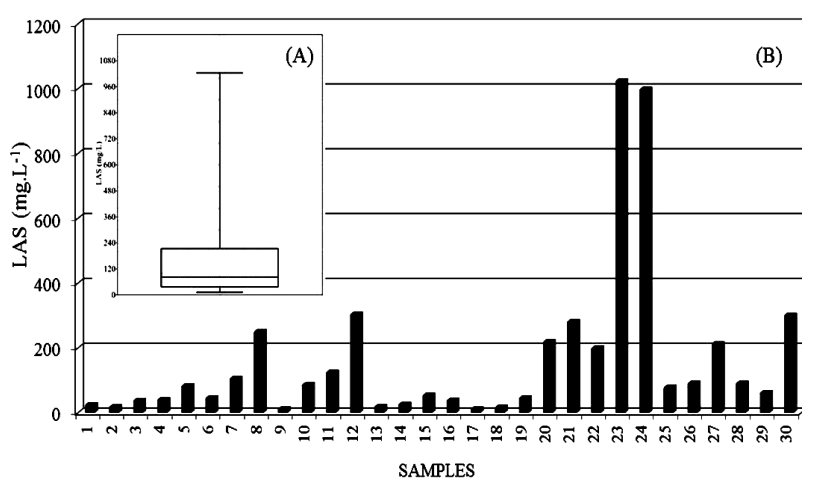

Figure 1. (A) Box-plot of LAS from the 30 samples and (B) histogram of LAS in each sample from the commercial laundry water. 
cationic (cetyltrimethyl ammonium bromide) and nonionic (tetrabromophenolphthalein ethyl ester) surfactants, were verified, respectively.

The Brazilian Agency for Sanitary Surveillance (ANVISA) considers n-dodecylbenzene sodium sulphonate (commercial LAS) as a standard for detergent biodegradability [22]. The degradation test described by ANVISA [23] involves an aerobic process and anionic surfactant quantification by the methylene blue active substance (MBAS) spectrophotometric method.

However, this method is not specific for LAS, as it quantifies anionic surfactants in general and is affected by interferents such as humic substances and other surfactants. MBAS will respond to any molecule with an anionic center capable of forming a stable ion pair with methylene blue and a hydrophobic group to allow the dye complex extraction into the chloroform phase [24]. The same MBAS response as $10 \mathrm{ppm}$ alkyl sulphate surfacetant was obtained for $1040 \mathrm{ppm}$ of nitrate and 17,900 ppm of $\mathrm{NaCl}$ (pH 1.8) [25].

Anionic surfactants may be found in the environment when raw or partially treated sewage is discharged. LAS concentrations in domestic sewage between $3 \mathrm{mg} \cdot \mathrm{L}^{-1}$ and $21 \mathrm{mg} \cdot \mathrm{L}^{-1}$ have been reported [26,27]. In India, the per capita detergent consumption was projected to increase by more than $4 \mathrm{~kg}$ per annum by 2005 [28].

\subsection{Physical-Chemical Analyses}

In relation the filtered and unfiltered COD was observed $622.25 \mathrm{mg} \cdot \mathrm{L}^{-1}$ to $4795.80 \mathrm{mg} \cdot \mathrm{L}^{-1}$ and $415.25 \mathrm{mg} \cdot \mathrm{L}^{-1}$ to $4473.25 \mathrm{mg} \cdot \mathrm{L}^{-1}$, respectively (Table 1 ). No pattern was found in relation to the effluent concentration of organic matter. In this study the correlation coefficients of Kendall (0313, $p=0.05)$ and Spearman $(0465, p=0.01)$ were positive correlations with COD and LAS.

Biological methods for domestic greywater treatment were studied [29]. The authors found $43.5 \pm 6.5 \mathrm{mg} \cdot \mathrm{L}^{-1}$ of anionic surfactant (using the MBAS method) and $827 \pm$ $204 \mathrm{mg} \cdot \mathrm{L}^{-1}$ of COD. Both values were below those found in this study.

A wide range of VFAs (volatile fatty acids) was found, the most common acids being propionic and isobutyric (100\% of samples), lactic (96.6\%), formic and acetic (93\%) and malic (73.3\%). The least common were caproic and succinic (16.6\%), valeric (26.6\%) and citric and butyric (33\%).

Lactic acid $\left(13.54 \mathrm{mg} \cdot \mathrm{L}^{-1}\right.$ to $406.75 \mathrm{mg} \cdot \mathrm{L}^{-1}$ ) was quantitatively the most representative, followed by isobutyric $\left(10.88 \mathrm{mg} \cdot \mathrm{L}^{-1}\right.$ to $\left.287.25 \mathrm{mg} \cdot \mathrm{L}^{-1}\right)$ and propionic $(10.66$ $\mathrm{mg} \cdot \mathrm{L}^{-1}$ to $279.75 \mathrm{mg} \cdot \mathrm{L}^{-1}$ ), respectively (Table 1 ). Although butyric acid was found in only $33.3 \%$ of the laundry water samples the values were above $200 \mathrm{mg} \cdot \mathrm{L}^{-1}$ in $40 \%$ of the samples containing this acid.

Among the alcohols analysed, only ethanol was pre- sent in $77 \%$ of samples, in which the average value found was $148.62 \mathrm{mg} \cdot \mathrm{L}^{-1}$.

In this study, the average $\mathrm{pH}$ was 5.6, and it ranged from 3.3 to 6.8. According to the Brazilian legislation [30], the proper $\mathrm{pH}$ value for effluent ranges from 5 to 9 . The average value recorded in this study fits within this standard, although some samples had a $\mathrm{pH}$ below the allowed value (33\% of samples). The São Paulo State Legislation [31] states that the effluent may be released into sanitary sewer system, only when provided with treatment and with a pH between 5 and 9. Thus, according to this legislation, $40 \%$ of the samples had an unsatisfactory $\mathrm{pH}$. The $\mathrm{pH}$ in grey water is directly related to the value in the water supply [7]. However, certain chemicals, such as fabric softeners, bleach and disinfectant, may contribute to the variation of this parameter.

The total alkalinity $\left(25.9 \mathrm{mg} \mathrm{CaCO}_{3} \cdot \mathrm{L}^{-1}\right)$ was low, as seen in Table 1 . Alkalinity values were reported ranging from $149 \mathrm{mg} \mathrm{CaCO} \cdot \mathrm{L}^{-1}$ to $198 \mathrm{mg} \mathrm{CaCO}_{3} \cdot \mathrm{L}^{-1}$ in domestic grey water [32]. Alkalinity is an important parameter when attempting to treat grey water from anaerobic digestion, whereas lowering the $\mathrm{pH}$ can harm the microorganisms responsible for organic matter degradation [7].

Low sulphate and sulphide concentrations were detected; whose average values were $6.21 \mathrm{mg} \cdot \mathrm{L}^{-1}$ and 0.17 $\mathrm{mg} \cdot \mathrm{L}^{-1}$, respectively (Table 1 ). In grey water was recorded $22.9 \mathrm{mg} \cdot \mathrm{L}^{-1}, 59.6 \mathrm{mg} \cdot \mathrm{L}^{-1}[32,33]$ and a maximum of $1000 \mathrm{mg} \cdot \mathrm{L}^{-1}$ of sulphate [31]. For sulphide, [30,31] allow effluent release with a maximum of $1.0 \mathrm{mg} \cdot \mathrm{L}^{-1}$. Therefore, both parameters were much lower than allowed.

Among the nitrogen compounds, nitrate had the greatest contribution $\left(8.37 \mathrm{mg} \cdot \mathrm{L}^{-1}\right)$, in other words, higher than that recorded in the literature [34] found 1.8 to 3.0 $\mathrm{mg} \cdot \mathrm{L}^{-1}$ of nitrate in a greywater treatment system. The value found for ammonia nitrogen was lower than that allowed by [30] (20 $\left.\mathrm{mg} \cdot \mathrm{L}^{-1}\right)$ for effluent discharge. This standard does not include other nitrogen forms. The total nitrogen concentration was close to that measured by [35], i.e., $40 \mathrm{mg} \cdot \mathrm{L}^{-1}$ in water laundry. The total nitrogen concentration of the grey wastewater is lower than in domestic sewage, 0.6 - 74 and 20 - $80 \mathrm{mg} \cdot \mathrm{L}^{-1}$, respectively [36]. Ammonium or nitrates are rarely used as counter-ions in personal care products or household chemicals [7].

Phosphate was detected in 93\% of the samples (94.65 $\mathrm{mg} \cdot \mathrm{L}^{-1}$ average); its strong presence was most likely due to the laundry water contents. Grey water contributes, in general, to $12.4 \%$ of the phosphorus load in a residence [37]. Laundry water may have a low phosphorus concentration due to the presence of phosphorus-free detergents [38]. However, when they are present, its main source is detergents containing phosphates [7]. In places where the use of these detergents is not allowed, the phosphorus in 
grey water tends to be $70 \%$ lower [39].

In the present study, the average total suspended solids content was $0.08 \mathrm{~g} \cdot \mathrm{L}^{-1}$ (Figure 2). Total suspended solids around $0.16 \mathrm{~g} \cdot \mathrm{L}^{-1}$ were found in other works [40] when studied the reuse and recycling of greywater. Greywater has a low suspended solids concentration, indicating that a large portion of the contaminants is in dissolved form [41]. Although the solids content expected in the greywater is lower when compared to conventional sewage [37], approximately $32.7 \%$ of sewage solids loading comes from greywater.

Measures of solids suspended in greywater have been reported in the literature in a range of $0.017 \mathrm{~g} \cdot \mathrm{L}^{-1}$ to 0.33 $\mathrm{g} \cdot \mathrm{L}^{-1}$. The highest values of which originated from laundries and kitchens [7]. The washing process loosens fabric fibres, varying in size up from rag fibers visible only under the microscope, which contributes to the build-up of solids in water cleaners.

\subsection{Metals in the Laundry Water}

Information about the presence of metals in various types of greywater from sources such as the bathroom, kitchen and laundry is currently limited to a few studies [4,7], and the knowledge regarding the removal of metals in greywater treatment systems is even more limited.

All metals analysed were below the maximum permitted value for effluent discharge according to [30] (Table 1). In this study, zinc was the most abundant $(0.56$ $\left.\mathrm{mg} \cdot \mathrm{L}^{-1}\right)$, followed by iron $\left(0.22 \mathrm{mg} \cdot \mathrm{L}^{-1}\right)$. Both were detected in $100 \%$ of samples. Nevertheless, the measured concentrations were below the maximum allowed, either by [30], or by the [31], which is $5 \mathrm{mg} \cdot \mathrm{L}^{-1}$ and $15 \mathrm{mg} \cdot \mathrm{L}^{-1}$ for zinc and iron, respectively. Only relatively low amounts of heavy metals in greywater have been reported in the literature. Domestic greywater reuse was studied [42]. The authors found $100 \mathrm{mg} \cdot \mathrm{L}^{-1}$ of zinc. Laundry wastewater contains, on average, $0.09 \mathrm{mg} \cdot \mathrm{L}^{-1}$ to $0.34 \mathrm{mg} \cdot \mathrm{L}^{-1}$ zinc [7]. The importance of household deter-

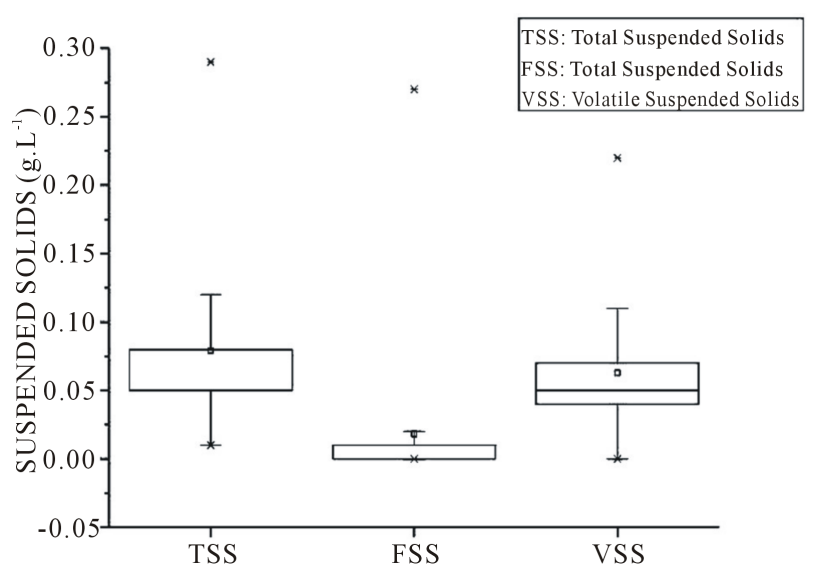

Figure 2. Solids suspended in greywater. gents, especially soap powder, as a significant source of cadmium, copper and zinc in sewage was emphasised [43].

\subsection{Xenobiotic Organic Compounds in the Laundry Water}

As many as 900 XOCs had been identfied [7] which are commonly used in bathroom and laundry products and hence potentially present in greywater. The major groups of the compounds were fragrances and flavours, preservatives, solvents and some surfactants, e.g., non-ionic and anionic surfactants (Tables 2 and 3).

Other groups included softeners and emulsifiers. The groups with only a few compounds were bleaches and dyes. These groups, however, are of special interest because they all contain bioactive compounds.

According to [44], more than 2500 individual chemicals are expected to be present in washing machine effluent and then in the raw sewage.

In this study, thirty-three different XOCs were identified in the laundry wastewater by qualitative screening. Identified substances were grouped into nine substance classes based on their application.

Among the compounds detected in laundry water by

Table 2. Xenobiotic organic compounds found in laundry wastewater.

\begin{tabular}{|c|c|c|c|}
\hline \multicolumn{4}{|c|}{ COMPOUNDS } \\
\hline Headspace analysis & $\% \mathrm{~A}$ & Liquid analysis & $\% \mathrm{~A}$ \\
\hline Butilcicloexil acetate & 3.2 & Octadecanoic acid & 0.61 \\
\hline Butanol & 70.96 & Palmitic acid & 1.67 \\
\hline Cis-dimetil ciclohexanol & 0.40 & Etil citrate & 5.88 \\
\hline $\begin{array}{c}\text { Decamethyl } \\
\text { cyclopentassiloxane }\end{array}$ & 1.50 & Cholesterol & 1.20 \\
\hline Dimetil ciclohexanol & 0.89 & Cicloexeno dimetil etil & 0.13 \\
\hline $\begin{array}{c}\text { Dodecametil } \\
\text { ciclohexassiloxano }\end{array}$ & 0.92 & Dimetil pentadecilamina & 0.62 \\
\hline Ethanol & 5.49 & $\begin{array}{l}\text { Diglicidil bisphenol } \\
\text { A eter }\end{array}$ & 0.40 \\
\hline Diphenyl eter & 0.52 & Etil hexil ftalato & 4.97 \\
\hline Octil fenil eter & 0.35 & Phenoxi ethanol & 0.39 \\
\hline Etil hexanol & 2.14 & Heptadecanol & 1.37 \\
\hline Isobornil formate & 1.18 & Hexadecanol & 1.80 \\
\hline Limonene & 1.82 & Isobutil phtalato & 0.22 \\
\hline Linalool & 3.04 & $\begin{array}{l}\text { Metil metóxi etil } \\
\text { octadecanamina }\end{array}$ & 3.15 \\
\hline Mercaptomethane & 2.04 & Nonylphenol ethoxilado & 8.85 \\
\hline $\begin{array}{c}\text { Octametil } \\
\text { ciclotetrassiloxano }\end{array}$ & 0.47 & Terpineol & 0.16 \\
\hline Metil sulfite & 0.6 & $\begin{array}{c}\text { Tetrametil butil } \\
\text { phenoxi ethoxilado }\end{array}$ & 3.48 \\
\hline Terpineol & 0.93 & & \\
\hline Tetradecene & 0.37 & & \\
\hline
\end{tabular}

$\% \mathrm{~A}=$ area percentage, which indicates the normalised relative distribution of the compounds in the sample. 
Table 3. Classes of compounds found in water and laundry.

\begin{tabular}{cc}
\hline Surfactant & Solvent \\
\hline Nonylphenol ethoxilate & Acetate of butyl cicloexyl \\
Tetramethyl butyl phenoxy & Butanol \\
ethoxilate & Cis-dimethyl cyclohexanol \\
Surfactant production & Dimethyl cyclohexanol \\
Cis-dimethyl ciclohexanol & Ethanol \\
Dimethyl ciclohexanol & Limonene \\
Diphenyl ether & Methyl sulfite \\
Tetradecene & Softener and plasticiser \\
Palmitic acid & Ethyl hexanol \\
Diglycidyl bisphenol A eter & Ethyl hexil phthalate \\
Decamethyl cyclopentassiloxane & Isobutyl phthalate \\
Dodecamethyl cyclohexassiloxane & Emulsifier \\
Octametil ciclotetrassiloxano & Octadecanoic acid \\
Pesticide/Repellent & Dimethyl ethyl \\
Limonene & cycloexene \\
Mercaptomethane & Heptadecanol \\
Diluent & Dimethyl pentadecylamine \\
Preservative and antioxidant & Miscellaneous \\
Phenoxy ethanol & Butyl cyclohexyl acetate \\
Hexpineol & Ether octyl phenil \\
Ether of diglycidyl bisphenol A & Isobornil formate \\
Limonene & Ethyl citrate \\
Linalool & Methyl metox ethyl \\
Methyl sulfite & \\
& \\
& \\
octadecanamina
\end{tabular}

headspace analysis, the solvents butanol (70.9\%) and ethanol (5.5\%) were the most common, followed by the fragrance linalool (3.0\%).

Between the compounds found in laundry water by direct injection analysis were citrate acetate (5.9\%), ethyl hexyl phthalate (5.0\%) and nonylphenol ethoxylate (4.7\%).

Both nonyl and tetramethyl butyl phenoxy ethoxylate were present in the laundry water. The group of alkyl phenols include several compounds that have come into focus because nonylphenol is an endocrine disrupter, i.e., a male and female reproductive toxicant [45]. Nonylphenol is used as a cleaning agent, softener and stabiliser but also as an intermediate in industrial processes [08]. The octylphenols and nonylphenols are frequently present in imported textiles, which then act as emission sources of those compounds [46,47]. Nonylphenol ethoxylate in greywater have been detected $[8,48]$.

Emulsifiers are used to prevent the separation of fats and water in a chemical product into two layers and are typically characterised by a polar and a non-polar moiety, long-chain fatty acids and their corresponding alcohols [8]. They were found to be present at relatively high levels, and include compounds such as hexadecanol and heptadecanol.

Three softeners and plasticisers were found, ethylhexanol and the phthalates ethylhexyl phthalate and isobutyl phthalate. Phthalate is a synthetic compound commonly used as a plasticiser to impart flexibility, workability, and durability to polymers such as polyvinyl chloride. Additionally, this compound is used in a wide variety of products such as paints, adhesives, inks and cosmetics [49, 50]. Di(2-ethylhexyl) phthalate (DEHP) is widely used as a plasticiser and may be sourced partly from PVC plumbing fixtures. Other household sources may be linked to its use in cosmetics, perfumes, lacquers, paints, pesticides, and printing inks for paper, plastics and textiles [51].

In all grey wastewater samples analysed by [8], nine softeners and plasticisers were found; the phthalates, bis(2-ethylhexyl)-, dibutyl-, diethyl-, dimethyl and mono ethylhexyl phthalate, dominate this group. Two other plasticisers similar in structure to di-(ethylhexyl) phthalate (DEHP) were identified as well: di-(ethylhexyl) adipate (diester of hexanedioic acid) and di-(ethylhexyl) sebacate (diester of decanedioic acid).

Cholesterol was the only sterol found in the laundry water, and it has previously been detected in greywater $[2,8]$.

Three terpene compounds were found in the laundry water, limonene, linalool and terpineol. Terpenes play an important role as fragrances in perfumery and detergents, as constituents of flavours for spicing foods, as medicines for the treatment of numerous diseases including tumours [52], in the pharmaceutical industry as an antifungal [53], and as an antiseptic [54].

Certain terpenes have been found to have some insecticidal activity. Alpha terpineol, menthol linalool and limonene have all been reported to possess insecticidal activity [55]. More than 40 fragrances and flavours were observed [8] in grey wastewater samples from Copenhagen, Denmark: citronellol, coumarin, eucalyptol, hexyl cinnamic aldehyde and menthol. This group is present as perfume additives in personal care products or as flavours in toothpaste.

Limonene, isoprenil-4-methyl-1-cyclohexene, is a monocyclic monoterpene that is present in more than 300 plants, mainly citrus fruits. There are various applications for limonene: as a solvent for resins, in rubber, in paints, as a dispersing agent for oil, as well as for use in the chemical synthesis of menthol [56]. Limonene has been used in household and industrial cleaning products [55]. The inhibitory effect of limonene was verified on various microorganisms [57]. A microencapsulation of limonene for textile application was verificed in other study [58]. 
Linalool is a monoterpene compound reported to be a major component of essential oils, in various aromatic species. Terpineol is a monoterpene with a pleasant odour and is found in a wide variety of essential oils with wide industrial applications [55].

Diglycidyl bisphenol A ether is used as a diluent for resins, as a textile treatment agent and as a stabiliser for chlorinated organic compounds. Bisphenol A is also used in the production of polycarbonate and can be leached from such materials if any excess monomer is present in the polymer matrix [59].

Table 3 lists all compounds present in the laundry and the classes into which they are subdivided. The current intense use of materials and substances causes diffuse source emissions that lead to the uncontrolled spreading of xenobiotic compounds to nature. The presence of these hazardous substances in the wastewater system raises increasing concerns, especially in view of the negative effects to the water and soil ecosystems as well as for the potential risks to human health.

\section{Conclusions}

From this study, it can be concluded that there is an urgent need for more information about the characteristics of laundry wastewater. The commercial laundry water studied had no consistent characteristics, and the content of study parameters varied from sample to sample. However, the vast majority of these parameters were lower than recommended by Federal and State Legislation, which does not minimise the environmental and public health impact. However, this does not eliminate the need for special treatment before the disposal of laundry wastewater in the sewage system because studies on the characteristics of laundry water and its potential effects are scarce yet.

Laundries have been found to be important sources in the diffuse spreading of many environmentally hazardous substances to wastewater. An inventory of laundry water chemicals revealed 33 xenobiotic organic compounds, including solvents, fragrances and auxiliary compounds to cleaning agent production, preservatives, insect repellents, antioxidants and others. This study also stresses the need for a thorough characterisation of grey wastewater and an evaluation of the possible sources of pollutants in grey wastewater, before reuse, to be able to establish the proper treatment method.

\section{Acknowledgements}

The authors gratefully acknowledge the Laboratório de Processos Biológicos-LPB/EESC/USP São Paulo, Research Foundation (FAPESP) (No 2010/11531-9) and the National Council for Scientific and Technological Development for their financial support.

\section{REFERENCES}

[1] T. Ivanković and J. Hrenović, "Surfactants in the Environment,” Arhiv za Higijenu Rada i Toksikologiju, Vol. 61, No. 1, 2010, pp. 95-110. http://dx.doi.org/10.2478/10004-1254-61-2010-1943

[2] J. Ottoson and T. A. Stenström, "Faecal Contamination of Greywater and Associated Microbial Risks,” Water Research, Vol. 37, No. 3, 2003, pp. 645-655. http://dx.doi.org/10.1016/S0043-1354(02)00352-4

[3] E. Friedler, "Quality of Individual Domestic Greywater Streams and Its Implication for Onsite Treatment and Reuse Possibilities,” Environmental Technology, Vol. 25, No. 9, 2004, pp. 997-1008. http://dx.doi.org/10.1080/09593330.2004.9619393

[4] E. Eriksson and E. Donner, "Metals in Greywater: Sources, Presence and Removal Efficiencies," Desalination, Vol. 248, No. 1-3, 2009, pp. 271-278. http://dx.doi.org/10.1016/j.desal.2008.05.065

[5] E. Howard, R. K. Misra, R. Loch and N. Le-Minh, "Laundry Grey Water Potential Impact on Toowoomba Soils," Final Report, National Centre for Engineering in Agriculture Publication 1001420/2, Toowoomba, 2005

[6] M. Abu-Zreig, R. P. Rudra and W. T. Dickinson, "Effect of Application of Surfactants on Hydraulic Properties of Soils,” Biosystems Engineering, Vol. 84, No. 3, 2003, pp. 363-372. http://dx.doi.org/10.1016/S1537-5110(02)00244-1

[7] E. Eriksson, K. Auffarth, M. Henze and A. Ledin, "Characteristics of Grey Wastewater," Urban Water, Vol. 4, No. 1, 2002, pp. 85-104. http://dx.doi.org/10.1016/S1462-0758(01)00064-4

[8] E. Eriksson, K. Auffarth, A. Eilersen, M. Henze and A. Ledin, "Household Chemicals and Personal Care Products as Sources for Xenobiotic Organic Compounds in Grey Wastewater," Water SA, Vol. 29, No. 2, 2003, pp. 135-146.

[9] E. Donner, E. Eriksson, D. M. Revitt, L. Scholes, H. C. Holten Lützhøft and A. Ledin, "Presence and Fate of Priority Substances in Domestic Greywater Treatment and Reuse Systems," Science of the Total Environment, Vol. 408, No. 12, 2010, pp. 2444-2451. http://dx.doi.org/10.1016/j.scitotenv.2010.02.033

[10] M. Cirja, P. Ivashechkin, A. Schäffer and P. F. X. Corvini, "Factors Affecting the Removal of Organic Micropollutants from Wastewater in Conventional Treatment Plants (CTP) and Membrane Bioreactors (MBR)," Environmental Science Biotechnology, Vol. 7, No. 1, 2008, pp. 61-78. http://dx.doi.org/10.1007/s11157-007-9121-8

[11] H. Palmquist and J. Hanæus, “A Swedish Overview of Selecting Hazardous Substances as Pollution Indicators in Wastewater," Journal of Environmental Management, Vol. 15, No. 2, 2004, pp. 186-203.

[12] APHA, "Standard Methods for Examination of Water and Wastwater," 21st Edition, American Public Health Association, Washington DC, 2005.

[13] R. Dilallo and E. Albertson, "Volatile Acids by Direct Tritation,” Journal WPCF, Vol. 33, No. 4, 1961, pp. 356365. 
[14] L. F. Ripley, W. C. Royle and J. C. Converse, "Improved Alkalimetric Monitoring for Anaerobic Digestion of Poultry Manure,” Proceedings of the 40th Industrial Waste Conference, 1986, pp. 141-149.

http://earchives.lib.purdue.edu/cdm4/results.php?CISOO P1=any\&CISOFIELD1=CISOSEARCHALL\&CISORO OT=/engext\&CISOBOX1=ETRIWC198515

[15] E. D. Penteado, C. Z. Lazaro, I. K. Sakamoto and M. Zaiat, "Influence of Seed Sludge and Pretreatment Method on Hydrogen Production in Packed-Bed Anaerobic Reactors," International Journal of Hydrogen Energy, Vol. 38, No. 14, 2013, pp. 6137-6145. http://dx.doi.org/10.1016/j.ijhydene.2013.01.067

[16] I. C. S. Duarte, L. L. Oliveira, A. P. Buzzini, M. A. T. Adorno and M. B. A. Varesche, "Development of a Method by HPLC to Determine LAS and Its Application in Anaerobic Reactors,” Journal of the Brazilian Chemical Society, Vol. 17, No. 7, 2006, pp. 1360-1367. http://dx.doi.org/10.1590/S0103-50532006000700025

[17] A. Gross, O. Shmueli, Z. Ronen and E. Raveh, "Recycled Vertical Flow Constructed Wetland (RVFCW) - A Novel Method of Recycling Greywater for Irrigation in Small Communities and Households," Chemosphere, Vol. 66, No. 5, 2007, pp. 916-923.

http://dx.doi.org/10.1016/j.chemosphere.2006.06.006

[18] M. Mccoy, "Soaps and Detergents," Chemical \& Engineering News, Vol. 82, No. 4, 2004, pp. 23-31. http://dx.doi.org/10.1021/cen-v082n004.p023

[19] A. Gross, N. Azulai, G. Oron, Z. Ronen, M. Arnold and A. Nejidat, "Environmental Impact and Health Risks Associated with Greywater Irrigation: A Case Study," Water Science \& Technology, Vol. 52, No. 8, 2005, pp. 161-169.

[20] A. Wiel-Shafran, Z. Ronen, N. Weisbrod, E. Adar and A. Gross, "Potential Changes in Soil Properties Following Irrigation with Surfactant-Rich Greywater,” Ecological Engineering, Vol. 26, No. 4, 2006, pp. 348-354. http://dx.doi.org/10.1016/j.ecoleng.2005.12.008

[21] L. H. Leal, H. Temmink, G. Zeeman and C. J. N. Buisman, "Characterization and Anaerobic Biodegradability of Grey Water,” Desalination, Vol. 270, No. 1-3, 2011, pp. 111-115. http://dx.doi.org/10.1016/j.desal.2010.11.029

[22] Brazil, "Biodegrabilidade dos Tensoativos Aniônicosparaprodutossaneantes Domissanitários," Surveillance Agency of the Health Ministry Ordinance No. 874 of November 5, 1998, Annex B (In Portuguese).

[23] Brasil, "Métodoparadeterminaçãopara a Biodegrabilidade de Tensoativosaniônicos," Surveillance Agency of the Health Ministry Ordinance No 393 of May 15, 1998, Annex A (In Portuguese).

[24] R. D. Swisher, "Surfactant Biodegradation,” Marcel Dekker, New York, 1987.

[25] H. C. Evans, "Determination of Anionic Synthetic Detergents in Sewage," Journal of the Society of Chemical Industry, Vol. 69, 1950, pp. 75-80.

[26] M. S. Holt, J. Waters, M. H. I. Comber, R. Armitage, G. Morris and C. Newbery, "AIS/CESIO Environmental Surfactant Monitoring Programme. SDIA Sewage Treatment
Pilot Study on Linear Alkylbenzene Sulfonate (LAS)," Water Research, Vol. 29, No. 9, 1995, pp. 2063-2070. http://dx.doi.org/10.1016/0043-1354(95)00020-L

[27] M. J. Scott and M. N. Jones, "The Biodegradation of Surfactants in the Environment (Review)," Biochemica et Biophysica Acta, Vol. 1508, No. 1-2, 2000, pp. 235-251. http://dx.doi.org/10.1016/S0304-4157(00)00013-7

[28] V. Pattusamy, N. Nandini and K. Bheemappa, "Detergent and Sewage Phosphates Entering into Lake Ecosystem and Its Impact on Aquatic Environment," International Journal of Advanced Research, Vol. 1, No. 3, 2013, pp. 129-133.

[29] L. H. Leal, H. Temmink, G. Zeeman and C. J. N. Buisman, "Comparison of Three Systems for Biological Greywater Treatment,” Water, Vol. 2, No. 2, 2010, pp. 155169. http://dx.doi.org/10.3390/w2020155

[30] Brazil, “Dispõe sobre a Classificação dos Corpos de Água e Diretrizes ambientais para o Seu enquadramento, Bemcomo estabelece as Condições e Padrões de Lançamento de Efluentes, e Dá outras providências,” National Council for the Environment Ordinance No 430 of May 13, 2011 (In Portuguese).

[31] Brazil, “Aprova o Regulamento da Lei n 997 Quedispõesobre a Prevenção e o Controle da Poluição do Meioambiente,” SÃO PAULO, Ordinancen, 8468 of September 31, 1976 (In Portuguese).

[32] J. B. Rose, G. Sun, C. P. Gerba and N. A. Sinclair, "Microbial and Persistence of Enteric Pathogens in Graywater from Various Household Source,” Water Research, Vol. 25, No. 1, 1991, pp. 37-42. http://dx.doi.org/10.1016/0043-1354(91)90096-9

[33] L. M. Casanova, C. P. Gerba and M. Karpiscak, "Chemical and Microbial Characterization of Household Graywater," Journal of Environmental Science and Health, Vol. 36, No. 4, 2001, pp. 395-401. http://dx.doi.org/10.1081/ESE-100103471

[34] C. P. Gerba, T. M. Straub, J. B. Rose, M. M. Karpiscak, K. E. Foster and R. G. Brittain, "Water Quality of Graywater Treatment System,” Water Research, Vol. 31, No. 1, 1995, pp. 109-116.

[35] D. Christova-Boal, R. E. Eden and S. Mcfarlane, "An Investigation into Greywater Reuse for Urban Residential Properties,” Desalination, Vol. 106, No. 1-3, 1996, pp. 391-397.

[36] M. Henze, P. Harremoes, J. La Cour Jansen and E. Arvin, "Wastewater Treatment Biological and Chemical Processes,” 3rd Edition, Springer, Berlin, 2001.

[37] S. R. Gray and N. S. C. Becker, "Contaminant Flows in Urban Residential Water System,” Urban Water, Vol. 4, No. 4, 2002, pp. 331-346. http://dx.doi.org/10.1016/S1462-0758(02)00033-X

[38] F. Li, K. Wichmann and R. Otterpohl, "Review of the Technological Approaches for Grey Water Treatment and Reuses," Science of the Total Environment, Vol. 407, No. 11, 2009, pp. 3439-3449. http://dx.doi.org/10.1016/j.scitotenv.2009.02.004

[39] R. Otterpohl, "Black, Brown, Yellow, Grey-The New Colors of Sanitation,” Magazine of the International Wa- 
ter Association, WATER, 21 October 2001, pp. 37-41.

[40] S. Trujillo, A. Hanson, W. Zachritz and R. Chancy, "Potential for Greywater Recycle and Reuse in New Mexico,” New Mexico Journal of Science, Vol. 38, 1998, pp. 293-313.

[41] O. R. Al-Jayyousi, “Greywater Reuse: Towards Sustainable Water Management,” Desalination, Vol. 156, No. 1-3, 2003, pp. 181-192. http://dx.doi.org/10.1016/S0011-9164(03)00340-0

[42] B. Jeppesen, "Domestic Greywater Reuse: Preliminary Evaluation,” Brisbane City Council, Department of Water Supply and Sewerage Report No. 60 Urban Water Research Association of Australia, Vol. 95, 1993, pp. 41-52.

[43] S. D. W. Comber and A. M. Gunn, "Heavy Metals Entering Sewage-Treatment Works from Domestic Sources," Journal of the Chartered Institution of Water and Environmental Management, Vol. 10, No. 2, 1996, pp. 137142. http://dx.doi.org/10.1111/j.1747-6593.1996.tb00023.x

[44] A. Marcomini and M. Zanette, "Chromatographic Determination of Non-Ionic Aliphatic Surfactants of the Alcohol Polyethoxylate Type in the Environment," Journal of Chromatography A, Vol. 733, No. 1-2, 1996, pp. 193-206. http://dx.doi.org/10.1016/0021-9673(96)00009-X

[45] National Toxicology Program (NTP), "The National Institutes of Health's, National Institute of Environmental Health Sciences,” 2011. http://ntp-server.niehs.nih.gov

[46] F. Höök, "Handdukar Med Ett Smutsigt Förflutet (Towels with a Dirty History)," Swedish Society for Nature Conservation, 2007. http://www.snf.se

[47] Testfakta, "Vinteroveraller för Barn (Winter Overalls for children)," 2007. http://www.testfakta.se/img/2007/11/9/21510.pdf

[48] H. Almqvist and J. Hanæus, "Organic Hazardous Substances in Graywater from Swedish Households,” Journal of Environmental Engineering, Vol. 132, No. 8, 2006, pp. 901-908.

http://dx.doi.org/10.1061/(ASCE)0733-9372(2006)132:8( 901)

[49] W. Ling, J. Gui-Bin, C. Ya-Qi, H. Bin, W. Ya-Wei and S. Da-Zhong, "Cloud Point Extraction Coupled with HPLCUV for the Determination of Phthalate Esters in Environmental Water Samples," Journal of Environmental Sciences, Vol. 19, No. 7, 2007, pp. 874-878. http://dx.doi.org/10.1016/S1001-0742(07)60145-4
[50] J. Huang, H. Wang, Q. Jin, Y. Liu and Y. Wang, "Removal of Phenol from Aqueous Solution by Adsorption onto OTMAC-Modified Attapulgite,” Journal Environmental Management, Vol. 84, No. 2, 2007, pp. 229-236. http://dx.doi.org/10.1016/j.jenvman.2006.05.007

[51] T. E. Økland, E. Wilhelmsen and Ø. Solevåg, “A Study of the Priority Substances of the Water," Framework Directive, Monitoring and Need for Screening, Norwegian Pollution Control Authority (SFT), 2005.

[52] E. Breitmaier, "Terpenes: Importance, General Structure, and Biosynthesis,” In: John Wiley \& Sons, Ed., Terpenes: Flavors, Fragrances, Pharmaca, Pheromones, WileyVCH Verlag GmbH \& Co. KGaA, Weinheim, 2006, pp. 1-9. http://dx.doi.org/10.1002/9783527609949.ch1

[53] D. Pitarokili, M. Couladis, N. P. Panayotarou and O. Tzakou, "Composition and Antifungal Activity on Soil-Borne Pathogens of the Essential Oil of Salvia sclarea from Greece," Journal of Agricultural and Food Chemistry, Vol. 50, No. 23, 2002, p. 6688. http://dx.doi.org/10.1021/jf020422n

[54] K. Kobayashi, "Factors Affecting Phytotoxic Activity of Allelochemicals in Soil," Weed Biology and Management, Vol. 4, No. 1, 2004, pp. 1-7. http://dx.doi.org/10.1111/j.1445-6664.2003.00112.x

[55] Jr. Wilkins, “Algaecide Composition and Methods of Removing Algae,” US Patent No. 5,856,272, 1999.

[56] G. A. Burdock, "Fenaroli's Handbook of Flavour Ingredients,” 5th Edition, CRC Press, Boca Raton, 1995.

[57] T. Chatterjee and D. K. Bhattacharyya, "Biotransformation of Limonene by Pseudomonas putida," Applied Microbiology and Biotechnology, Vol. 55, No. 5, 2001, pp. 541-546. http://dx.doi.org/10.1007/s002530000538

[58] S. N. Rodrigues, I. Fernandes, I. M. Martins, V. G. Mata, F. B. Alirio and E. Rodrigues, "Microencapsulation of Limonene for Textile Application,” Industrial \& Engineering Chemistry Research, Vol. 47, No. 12, 2008, pp. 4142-4147. http://dx.doi.org/10.1021/ie800090c

[59] G. S. Leite, R. J. C. F. Afonso and S. F. Aquino, “Caracterização de Contaminantes Presentes em Sistemas de Tratamento de Esgotos, por Cromatografia Líquida Acoplada à Espectrometria de Massas Tandem em Alta Resolução,” Química Nova, Vol. 33, No. 3, 2010, pp. 734-738.

http://dx.doi.org/10.1590/S0100-40422010000300044 